\title{
OFICINA SOBRE A REUTILIZAÇÃO DAS ÁGUAS CINZAS - CÍRCULO DO MAMOEIRO: CONSTRUINDO SUSTENTABILIDADE
}

\author{
Apresentação: Relato de Experiência \\ Maria Dinaiza de Lima Ferreira ${ }^{1}$; Joana Darck Pê Nero ${ }^{2}$; Samara Santos de Macena ${ }^{3}$ J Jaciara \\ Ferreira Gonçalves ${ }^{4}$; Alexandre Eduardo de Araújo ${ }^{5}$
}

\section{Introdução}

Por ser a marca do século XXI, a crise de água torna-se um assunto do interesse de alguns, à medida que conseguem transformar a escassez em vantagens. Mesmo com tantos avanços culturais, sociais e tecnológicos, as mudanças e as inovações que conduzem ao desenvolvimento sustentável se tornam distantes em muitos países e, em particular, na região Nordeste do Brasil. Partindo dessa problemática, são pensadas diversas formas de reutilizar água. Usar as chamadas "águas cinzas" (águas provenientes de pias e banheiros) para irrigar plantações, é uma excelente opção.

\section{Relato de Experiência}

Para a realização da oficina foi apresentado o círculo do mamoeiro, uma técnica usada para tratar as águas das casas e ainda beneficiar a produção de mamões. Segundo VIEIRA (2008), essa técnica originou-se da observação dos efeitos de fortes ventos sobre a cultura dos cocos, onde os coqueiros caídos davam origem à círculos de coqueiros que nasciam, se desenvolviam e produziam melhor do que quando sós. No caso dos mamoeiros, percebeu-se que eles, como outras plantas de folhas largas como a bananeira, evaporavam grandes quantidades de água. Estabeleceu-se, assim, uma relação com as águas cinzas das residências. Essa atividade foi uma ação realizada por meio do curso de extensão, intitulado "JUVENTUDE RURAL: fortalecendo a inclusão produtiva na Zona da Mata e Brejo Paraibano", projeto esse que visa contribuir com a inserção social na busca da autonomia intelectual e econômica de jovens do campo. Sua proposta metodológica parte dos princípios da Pedagogia da Alternância, onde os jovens passam por formação teórica e prática nos tempos comunidade (atividades presenciais com visitas de intercâmbio às comunidades) e escola (aulas teóricas e práticas).

\footnotetext{
${ }^{1}$ Licenciatura em Pedagogia, CCHSA/UFPB, dinalima_02@hotmail.com

${ }^{2}$ Licenciatura em Ciências Agrarias, CCHSA/UFPB, Darck1818@gmial.com

${ }^{3}$ Técnica em Agropecuária, CAVN/UFPB, samaramacena2015@gmail.com

${ }^{4}$ Docente, CCHSA/UFPB, alexandreeduardodearaujo@ hotmail.com
} 
A prática desta atividade se deu com a construção de um buraco em forma de concha, com $1 \mathrm{~m}^{3}$ de volume, onde a terra retirada dele é colocada na borda, aumentando a altura do buraco. Depois de pronto, o buraco é preenchido com madeira e palha para criar um ambiente adequado para o recebimento das águas cinzas e para beneficiar a micro vida. Depois de pronta a cova, foi realizada a plantação das mudas do mamoeiro, em covas de dimensões de 30x30x30cm, as quais foram preenchidas com matéria orgânica para proteger o solo e proporcionar melhor crescimento da cultura.

Imagem 1: Construção da cova. Fonte: Própria.

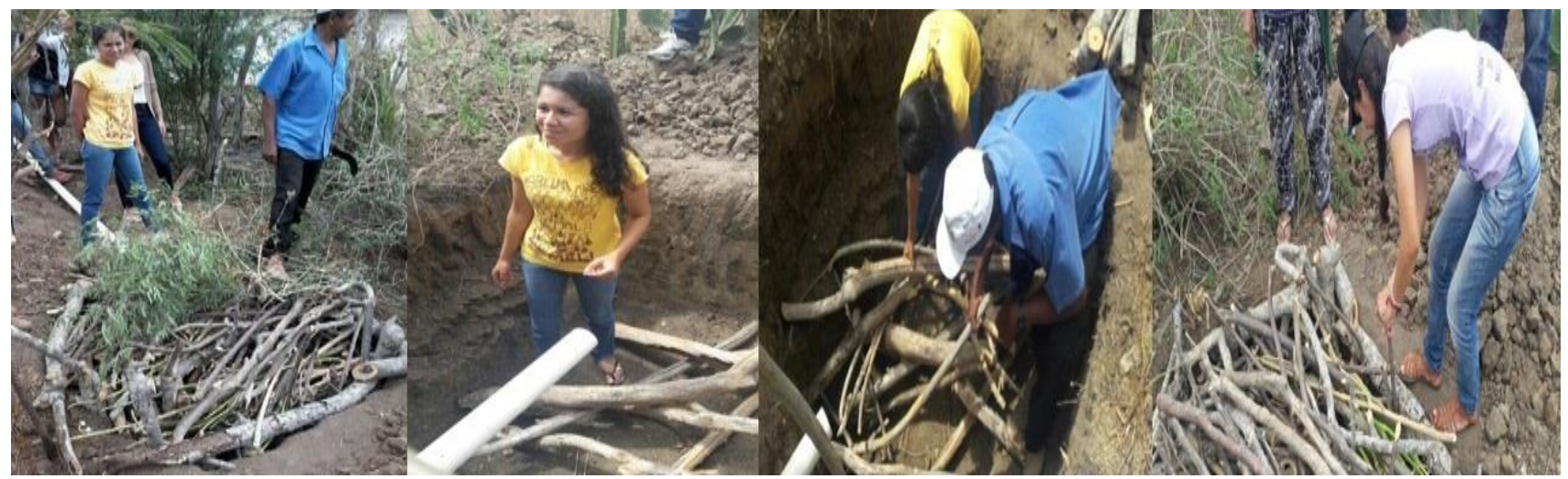

\section{Considerações}

A oficina foi um mecanismo dinâmico de troca de saberes empíricos e científicos, que proporcionaram a promoção dos produtores e possibilitaram que eles, usassem os conhecimentos adquiridos na otimização do seu sistema produtivo. As discussões possibilitaram identificar as potencialidades do reuso de água no cultivo do mamão, onde essa, apresenta-se como uma alternativa sustentável de cultivo.

\section{Referências}

VIEIRA, Itamar. Círculo de bananeiras. http://www.setelombas.com.br/2006/10/14/circulo-debananeiras>. Acessado em: v. 12, n. 11, p. 2008, 2006.

REBOUÇAS, A.C. Água na região Nordeste: desperdício e escassez. Estud. av. vol.11 no.29 São Paulo, 1997, p. 127-154. 